\title{
CROSS-BORDER APPROACH TO REGIONS' SMART SPECIALIZATION: EXPERIENCE OF THE EU MEMBER STATES
}

\author{
OLHA DEMEDYUK, KHRYSTYNA PRYTULA
}

\begin{abstract}
In the recent decade, the EU Member States have been actively implementing the regional development policy based on innovative strategies of smart specialization. However, lately, European researchers have been paying increasing attention to the issues of regions' capacity to overcome the boundaries of administrative units inside the country and abroad and to the need to consider regions in the context of their functioning among others, especially from the viewpoint of the growing role of their innovative networks in global value chains. That is why currently the EU is addressing the development of cross-border smart specialization strategies.

The paper aims to study the European experience on the functioning of cross-border innovation systems and joint strategic planning of cross-border regions' development based on smart specialization and to outline the opportunities to implement the EU experience of cross-border approach to smart specialization in cross-border regions of Ukraine with EU Member States.

The paper analyzes the views of foreign researchers on the links between innovation systems in cross-border space that constitute the theoretical basis of the study of cross-border smart specialization strategies, namely regarding the dimensions and level of their development. The research of European scientists on cross-border innovation systems in specific cross-border regions is examined, in particular on Spanish-French and German-French borders.

Directions of implementation of smart specialization projects in cross-border context under the EU programs and other EU instruments that support regions in cooperation for the elaboration of joint view of development with neighbouring economically, socially, culturally, and historically close regions are outlined.

The experience and methodology of the first cross-border smart specialization strategy for Spanish and Portuguese regions are studied in detail.

The opportunities to use the EU experience by several Western Ukrainian regions based on the joint smart specialization priorities with the neighboring EU states are outlined. For this purpose, 1) the RIS3 strategies of the regions of Poland and Romania adjoining Ukraine and Regional Development Strategies of respective Ukrainian regions were analyzed to detect similar smart specialization priorities; 2 ) the clusters in the mentioned regions were analyzed as main drivers of achievement of smart specialization goals to detect similar or complementary functioning areas.
\end{abstract}

Keywords: regional innovation systems, cross-border innovation systems, EU Member States, smart specialization, cross-border region, cross-border smart specialization strategy, RIS3, clusters.

JEL Classification: F02, O31, R11. 


\section{INTRODUCTION}

In conditions of a deep economic crisis in the EU that occurred in the 2007-2013 program period, the endeavors of the EU Member States were focused on the search for ways to boost smart, sustainable, and comprehensive growth. Moreover, innovative growth has come into the spotlight. In particular, the Communication from the Commission to the European Parliament, the Council, The European Economic and Social Committee and the Committee of the Regions Europe 2020 Flagship Initiative Innovation Union was adopted in 2010 [1]. The document emphasizes the investment in research, innovations, and entrepreneurship for the most efficient use of the countries' capacity. The issues of innovative activity and investment are at the heart of Strategy 2020. The new 2014-2020 cohesion policy defines smart specialization as a strategic approach to boosting economic growth through efficient support for research and innovations. It has become the platform for joining the endeavors of regional and state authorities in the EU to develop innovative smart specialization strategies from the viewpoint of efficient use of structural funds and growing synergy between national and regional policies of the EU countries and the policy of the Community.

A region cannot exist separately in the modern world. To develop efficiently, it should take into account the factor of growing international cooperation both in production and sales as well as in research and innovation. Therefore, the regional innovation strategies for smart specialization (RIS3) will be the most successful if the regions are examined in the context of their functioning among other regions, especially from the viewpoint of the growing role of their innovative networks in the processes of integration into global value chains. The cross-border smart specialization strategies have been gaining much attention lately in the EU. One of them is already developed and is being implemented. Such strategies are grounded on the processes of data and information exchange, joint projects implementation, and development policies harmonization in various domains.

The EU-Ukraine Association Agreement stipulates that the latter should have brought its legislation in compliance with the EU legislation by 2025. The introduction of the smart specialization concept into the system of strategic planning of regional development is one of the required changes. The Resolutions of the Cabinet of Ministers of Ukraine № 931 and 932 as of 11 November 2015 were amended to create the legal ground to introduce the smart specialization approach into the process of strategic planning in Ukraine. The regional development strategies for the period by 2027 for all oblasts have been finalized already. Most Ukrainian oblasts are located close to the state border and the border itself and the phenomena it generates as well as similar features of economic and social systems on both sides of the border should have been taken into account. Yet, the analysis of regional development strategies for 5 Western oblasts of Ukraine that border the EU shows that although the cross-border cooperation is mentioned in them mostly in the context of joint implementation of projects and tourism, the priorities of smart specialization in the neighboring regions are not examined and the opportunities of using the similarities of the regions on both sides of the border to boost their innovative and sustainable development are overlooked. Meanwhile, Ukraine has experience of participating in crossborder strategies - the Cross-Border Cooperation Strategy of the Lubelskie Voivodeship, Lviv, Volyn and Brest Oblasts for 2014-2020 and the 2020 Strategy of the Development of Slovakian-Ukrainian Cooperation (Oriented at the Development of Cooperation between the Presov and Kosice SelfGoverning Regions of Slovak Republic and Zakarpatska Oblast of Ukraine). Both of them are terminating this year. Therefore, it is essential to examine the experience of EU regions in developing cross-border smart specialization strategies and estimate them from the viewpoint of opportunity to be applied in Ukraine in strategic planning of cross-border and border regions' development.

The paper aims to examine the experience of the EU countries regarding the functioning of crossborder innovation systems and joint strategic planning of the development of cross-border regions based on smart specialization principles and to outline the opportunities to implement the EU experience of cross-border approach to smart specialization in cross-border regions of Ukraine with EU Member States. 


\section{THEORETICAL BACKGROUND}

The research of cross-border innovation systems that constitutes the ground for cross-border smart specialization is rather new and starts in the current decade of the XXI century. K.-J. Lundquist and M. Trippl emphasize that the cross-border innovative systems should be considered as the most developed forms of transnational integration that are based on the previous less innovatively oriented development models. The authors suggest five dimensions of regional innovation systems (RIS). On this ground, they delineate the factors that impact the capacity of a cross-border region to carry out a joint innovative activity, which are the basis for determining three development levels of cross-border innovation systems [2].

The first RIS dimension is the science base/knowledge infrastructure. It is the subsystem of knowledge generation and diffusion through research, education, and technology transfer establishments. The second RIS dimension is the economic structure/specialization pattern. It is the subsystem of knowledge application that includes the companies and clusters functioning in the region. The knowledge, resources, and human capital flows between the two subsystems create the third dimension - the nature of linkages. The fourth dimension covers the policy structures - the regional policy in the area of innovations. The institutional set-up is the fifth dimension that represents the available institutional and socio-cultural situation in the region, including both formal and informal institutions.

The weakly integrated systems are the first development level of cross-border innovation systems. They are characterized by a low level of cross-border economic relations, in particular, the knowledge and innovations exchange. The authors argue that most Euroregions show this development level due to lacking synergy or poor use of the synergy. Lacking synergy is caused by substantial differences in scientific specialization, knowledge systems, and economic structures (cognitive distance). The authors also mention that the regions shouldn't be very close by the mentioned parameters because the cooperation won't generate new knowledge. The regions can be similar by the models of scientific or economic specialization but differ by innovative capacity or ability to absorb innovations. In this case, the results of cooperation can be distributed unequally (functional distance). Poor use of the synergy occurs mostly due to differences in institutional systems of the regions (institutional distance) and obstacles in the accessibility of the regions (physical distance). In this context, the authors emphasize the need for investment in cross-border infrastructure and the development of cross-border institutions.

The semi-integrated systems are the second level of development of cross-border innovation systems. They are characterized by the emergence of the system grounded on knowledge. According to the authors, although some clusters demonstrate the necessary level of cognitive and functional distance, most of them do not represent the complex cross-border innovation system despite being innovative. Compared to the first development level, the negative impact of physical distance is lower. There are more opportunities for the exchange of students, researchers, specialists, the establishment of scientific cooperation, and science-education-industry partnerships.

Strongly integrated systems are the highest development level of cross-border innovation systems. They are characterized by a strong knowledge, experience, and skills flows across the border that are generated by growing students and workers mobility, emerging innovative network links between the companies, and science-education-industry partnerships. The synergy comes from a high level of functional distance and optimal level of cognitive distance in business systems and knowledge bases. Such synergy occurs not in few but in many economic and scientific activity domains. The transport and communication infrastructure is well developed and contributes to high accessibility. There are joint institutions that are involved in overcoming the socio-institutional obstacles. They might not be directly related to innovative activity, but they create the necessary environment for the development of all cooperation areas. The joint solution of problems at the cross-border level becomes part of everyday life and is supported by society. 
The research of the RIS dimensions continues in the studies of van den Broek and Smulders [3]. Yet, the researchers examine only certain dimensions or their parts, while the concept of RIS multidimensionality, in general, is underresearched.

Adi Weidenfeld argues that tourism is one of the key factors of the cross-border innovation systems' evolution because it impacts directly the development of transport and border infrastructure that reduces the border function as a physical barrier in the weakly integrated systems [4]. The issue of geographic delineation of innovation systems is studied by Doloreux and Parto [5]. Makkonen and Rohde [6] examine the issue of delineating the cross-border region only geographically rather than by the intensity of links, namely the innovative ones. There are several scientists studying the cross-border innovation systems by economic sectors, for example, van den Broek and Smulders [3] and Hansen [7].

In Ukraine, the development of national and regional innovation systems is addressed by $\mathrm{Y}$. Bondaruk, S. Horblyuk, I. Mushenyk, A. Poruchnyk, S. Prohorchuk, L. Fedulova, etc. But the forming and functioning of cross-border innovation systems and elaboration of cross-border regions' strategies based on smart specialization require more attention and examination.

\section{RESULTS}

Many European regions consider their geographical position as well as history and perspectives of cooperation with other regions when strategizing their development on the principles of smart specialization. In this regard, the perspective areas of cooperation with neighboring regions of a country, geographically close regions of adjoining countries, and even cooperation on the international scale are often covered by the RIS3 strategies. For example, the RIS 3 Strategy of S. Voivodeship defines 4 strategic partners to boost the innovative capacity of the region: Molopolskie and Opolskie Voivodeships, Moravian-Silesian Region of the Czech Republic, and Zylina Region of Slovakia. Three main directions of cooperation are defined: business or commerce, science, and implementation of the research results [8]. The first direction includes cooperation between organizations of entrepreneurs and clusters, joint initiatives on the intensification of trade operations, informing about legal and administrative documents on carrying out commercial activity abroad, and organizing economic forums, etc. The other two directions emphasize the need to increase the number of large strategic projects implemented mostly by universities, technological parks, and representatives of business or economic departments of local governments. Cooperation is primarily related to production technologies, non-traditional renewable energy sources, and ICT. All activities accomplished under these three directions are supported by mobility programs for students, academic staff, and company employees. Implementation of these directions is secured by the Tritia EGTC founded by Silesian Voivodeship, Moravian-Silesian Region of Czech Republic and Zylina Region of Slovakia, in the framework of cooperation agreements between 11 universities at the Poland-Czech Republic-Slovakia border on innovative activity in PROGRES3 consortium, and between Polish and Czech universities in the framework of the Conference of Rectors of Silesian Universities.

Joint implementation of competitive advantages with regions similar or complementary by their specialization areas is seen as one of the ways to achieve the smart specialization goals. North Holland (the Netherlands) traditionally actively cooperates with Scane County of Sweden and northern regions of Germany in realizing similar smart specialization priorities. On an international scale, in 2015, North Holland signed a bilateral agreement with Romanian North-East Region with the view to jointly react to social challenges and boost the economic growth of regions by creating regional innovative incubators and living labs that are the tools to implement smart specialization priorities providing the companies with the space to exchange ideas, carry out the innovative activity, and receive various types of support [9].

Flanders region of Belgium was the pioneer of multi-regional cooperation for smart specialization by launching in 2013 the Vanguard Initiative "New Growth through Smart-Specialization" [10]. It is focused on consolidating the authorities of EU regions to search for ways to impact the European employment and economic growth policies, namely in innovations and industrial policy. The regions 
work to transform regional partnerships and clusters defined by the smart specialization strategies into world-level clusters that can compete on an international scale. In the context of the large-scale international cooperation of regions to implement the smart specialization goals, the High Tech Farming partnership should be mentioned. It was initiated by Italian Toscana under the Agri-Food Thematic Smart Specialization Platform. The Partnership consolidates 26 EU regions and one country to develop joint activities on the acceleration of the implementation of advanced technologies that can boost the activity of farms. Within its framework, the complementarity areas among the partners are defined, information on perspectives and needs of regional actors across technological sectors is collected, many interested parties from various activity types, including clusters, are attracted, and a lot of micropartnerships are created to participate in funding programs according to joint or similar smart specialization priorities [9].

Clusters are the key tools used by European regions to achieve the goals of smart specialization. Their role is mentioned in almost every RIS3, including in the context of overcoming the borders of one region and even the state to consolidate the competitive advantages of territories. No wonder that Flanders is the region that promotes the multi-regional smart specialization by the development of clusters. It is due to the fact that its RIS3 is fully based on the regional clusters policy that is horizontal and vertical (for spearhead clusters). Another region grounding its smart specialization policy on clusters is Lapland (Finland) [11]. Due to active EU policy that encourages clusters to overcome the internal borders of the regions and countries, a lot of them form cross-border and international partnerships that in time turn into cross-border and international clusters. The most known are those in pharmaceuticals and medical technology: the Medicon Valley with partners from Denmark and Sweden that consolidates over 85 biotechnological, 27 pharmaceutical, 166 medtech companies, scientific parks, 6 incubators, 97 research organizations, 32 hospitals, 12 universities, 32 labs, 25 investment companies, and 17 civil organizations to treat neural disorders, cancer, and diabetes; and the Bio Valley that consolidates over 600 pharmaceutical companies and 14 scientific parks as well as numerous economic development agencies and civil organizations from adjoining regions of France, Germany, and Switzerland. "BIG-Cluster" functions at the Dutch-Belgian-German border in the biorenewable energy domain. Another new initiative at this border section is the Top-Technology-Cluster. The large network clusters in Europe include The European Railway Clusters Initiative (ERCI) that covers 14 innovative clusters from 10 countries and the Transnational Renewable Energy Cluster Danube (TREC Danube) that consolidates regional clusters in renewable energy and bioeconomy [12].

In the last two program periods, many European regions attempted to attract EU funding to examine the opportunities of cooperation with neighboring regions to boost the innovative and scientific capacity of their territories. One of the projects is KNOWHUB (regions from Poland, Hungary, Spain, France, Austria, Germany, Bulgaria) under INTERREG IVC, which organized the activities on experience and knowledge exchange for more efficient implementation of S3 strategies [13]. Another project is TR3S implemented by regions from Finland, Germany, Poland, Romania, Italy, Estonia, Great Britain, Hungary, and Spain to detect the unique features of each region and its competitive advantages [14]. France and Spain are implementing the project aCCeSS - Cross-Border Cooperation for Smart Specialization under the INTERREG Poctefa 2014-2020 to promote the transfer of knowledge and technology from research institutions to business with the view to expand the capacity and introduce innovations [15]. In the program period 2007-2013, the project "Smart Specialization" of the regions from Greece and Bulgaria stipulated examining of available competitive advantages in neighboring regions of the country and their innovative and scientific capacities to create the ground for writing joint strategies oriented at innovations and entrepreneurship in the following program periods [16].

It is worth mentioning that the initiatives regarding the elaboration of joint development strategies emerge mainly in the border regions that have the significant experience of cooperation within Euroregions, primarily due to the fact that such regions mostly have close internal links and have joint managing bodies. Mikel Navarro, the researcher of cross-border links between the Euskadi Region (the Basque Country) and neighboring regions, emphasizes the innovation and knowledge cooperation as a precondition for joint strategic planning of their development [17]. Being the member of EGTC 
Nouvelle-Aquitaine-Euskadi-Navarra, the region participated in projects related to innovations in cross-border space, its strategic and program documents and institutional environment of innovations support in the region and those of the other regions-members of the EGTC have similar features. The region is also active in promoting cross-border innovative cooperation in Europe. Therefore, the Euskadi academic community is turning to developing the cross-border smart specialization strategies with adjoining regions of the neighboring countries in correspondence with the respective thematic and horizontal S3 priorities.

Academic community is also emphasizing the readiness of another cross-border region in Europe to implement a joint strategic approach to its development as an integrity - Upper Rhine on the border between Germany, Switzerland, and France. For example, E. Muller, A. Zenker, M. Hufnagl, J. Alain Heraud, E. Schnabl, T. Makkonen, H. Kroll [18] outline the issue of innovation policies coordination in Upper Rhine as a ground for implementing the joint smart specialization concept. From the viewpoint of the decades-lasting active cooperation in the region, the joint approach to smart specialization can promote the further deepening of existing links across borders. The results of the sociological survey in these regions show that France and Germany have similar socio-economic development trends, governance systems, and political traditions in the context of smart specialization development. The regions Alsace and Baden-Württemberg have very close cultural, historical, and economic links. They are characterized by high level of innovations development and powerful scientific capacity. The regions also use joint approaches to innovation policy and are specialized in similar economic activities. Therefore, the grounds for elaborating the $\mathrm{S} 3$ for the cross-border region are quite strong.

The most successful in joining efforts to boost socio-economic development based on smart specialization are Spain and Portugal, which have produced the first cross-border smart-specialization strategy [19]. With the view to improve the efficiency of the use of various financial sources, including the regional operational programs and cross-border cooperation programs, the regional authorities of Galicia (Spain) and Norte (Portugal) started in 2014 the joint process of strategic planning. They established a cross-border Working Group consisting of the Galician Innovation Agency and the Regional Coordination and Development Commission of the North. It generated a joint view of innovative development and harmonization of its goals as well as joint priorities, necessary activities, and the system of indicators to monitor the cooperation efficiency.

The Strategy was preceded by an over 30-year history of cooperation between these regions in the framework of the Euroregion Galicia-Northern Portugal, which was one of the first to become a legal entity and is now functioning as an EGTC. Local authorities and cross-border cooperation participants are also members of 2 more EGTCs. In the decades of cooperation, many joint projects and activities were implemented in innovations, research, and business, generating the necessary background for detecting similar features and priorities of the regions' development. Among those most essential for innovative development is the common education platform that consolidates 6 universities, the emergence of the textile cluster, and the founding of cross-border development, cooperation and business services center CECOTRAN, which is the legal entity and functions to create strong networks and platforms for cooperation between small and medium companies and exchange of data, experience, and development initiatives. The importance of writing the joint strategy was emphasized in the 2014 Joint Investment Plan of the Euroregion Galicia - Northern Portugal under the Priority Axis 1 "An innovative Euroregion advocating innovation and transfer".

2015-2020 Cross-Border Smart Specialization Strategy of Galicia-Northern Portugal is based on recommendations provided by RIS3 Guide. Therefore, in accordance with the Guide, the Strategy was developed in 6 key stages. The first stage included a detailed analysis of regions' cooperation in the Euroregion and in research and innovations. The second stage stipulated the diagnostics of innovation and research system of the Euroregion. Production specialization in the Strategy is calculated by the Relative Production Specialization Index by comparing a region's value with the value of the country in general in each economic sector. Technological specialization is determined based on the data of the Innovation Observatory of Galicia on participation in projects by the Sectoral Programmes at the regional level, R\&D grants from public institutions at the national level (namely, the Technological 
Development Centre of Spain) and in the Seventh Framework Programme at the international level. Technological specialization for Northern Portugal was calculated by comparing the Relative Technological Specialization Index in comparison with OECD countries. Scientific specialization was determined by participation in project calls at regional, national, and international levels.

At the third stage, the shared vision and principles of regions' development, as well as challenges faced by the cross-border region in convergence with other EU regions, were developed. In this regard, the survey of main entities and participants of innovation activity was carried out at both sides of the border to reveal their readiness for cross-border cooperation and to detect the EU programs they would like to participate in.

The fourth stage is directly related to the selection of cooperation areas. Based on analysis carried out at the second stage and diagnostics carried out for preparation of RIS3 of Galicia and Northern Portugal, 6 strategic cooperation areas were selected for these regions. They are the marine and biomass energies, agri - bio, food industry, processing industry, aeronautics, creative industries, ICT and tourism, health and active aging. The fifth stage outlines the process of Strategy implementation and defines the entities responsible for the process. And the final sixth stage covers the methodology of evaluation and monitoring of the Strategy implementation.

European Union has developed the system of tools to encourage regions to cooperate in the development of joint strategic documents and achievement of practical results in a synergy of priority directions to stimulate economic development. They include the interactive tool for Regional Benchmarking that helps identifying regions with similar structural conditions in terms of innovative development (social, economic, technological, institutional, and geographical features); Eye@RIS3 database that provides the review of priorities of regional and national smart specialization strategies and opportunity for the regions to position themselves, find their unique niches, and search for partners for cooperation; and interactive application for the visualization of international trade flows and analysis of regions' competitive positions [20]. There is also a range of specific EU tools for the regions that ground their smart specialization policies on the development of clusters.

\section{DISCUSSION}

To reveal if there are grounds for cross-border regions of Ukraine to apply a smart specialization approach to strategizing their development, we focus on two of them - Ukraine-Poland and UkraineRomania. For this purpose, 1) the RIS3 strategies of the regions of Poland and Romania adjoining Ukraine and Regional Development Strategies of respective Ukrainian regions were analyzed to detect similar smart specialization priorities; 2 ) the clusters in the mentioned regions were analyzed as main drivers of achievement of smart specialization goals to detect similar functioning areas.

In this regard, it is worth mentioning that Ukraine started to apply the smart specialization principles in strategizing only this year, so we had to compare RIS3 of European regions from the current program period with Regional Development Strategies of Ukrainian regions for the next 20212027 period. Moreover, although the smart specialization approach was applied in Ukraine, it was not completely based on the one used in the EU due to the lack of necessary statistical data. The priority areas in Ukraine were determined according to the national Classifier of Economic Activity Types, while priorities in the EU are mostly cross-sectoral, therefore - much broader than in Ukraine.

In addition to this, out of the neighboring EU countries (Poland, Slovakia, Hungary, Romania), Slovakia and Hungary, in the current program period, have smart specialization strategies only at the national level. Therefore, similar priorities were analyzed for two cross-border regions - UkrainePoland and Ukraine-Romania. The results of the analysis are presented in Tables 1 and 2. 


\begin{tabular}{|c|c|c|}
\hline $\begin{array}{c}\text { Region of } \\
\text { the } \\
\text { neighboring } \\
\text { state }\end{array}$ & $\begin{array}{l}\text { Smart specialization priority of the region of the } \\
\text { neighboring state }\end{array}$ & $\begin{array}{l}\text { Similar priorities of } \\
\text { Ukrainian regions within the } \\
\text { respective cross-border region }\end{array}$ \\
\hline \multirow[t]{2}{*}{$\begin{array}{c}\text { Lubelskie } \\
\text { voivodship }\end{array}$} & $\begin{array}{l}\text { Bioeconomy. The use of agricultural and industrial } \\
\text { biotechnology, nanotechnology, biophysics in the } \\
\text { value chains of sustainable primary production, bio- } \\
\text { resources and food production in the sectors of } \\
\text { pharmaceutical, energy, eco-business, agro-food, } \\
\text { chemical, paper, wood and furniture, information } \\
\text { services. }\end{array}$ & $\begin{array}{l}\text { Food production, chemical } \\
\text { production, manufacturing } \\
\text { paper and cardboard products, } \\
\text { furniture production (Lvivska } \\
\text { oblast). } \\
\text { Stimulating the development } \\
\text { of balanced eco-friendly food } \\
\text { (Volynska oblast). }\end{array}$ \\
\hline & $\begin{array}{l}\text { IT \& automation. The use of mechatronics, smart } \\
\text { buildings, control systems, industrial automation and } \\
\text { mobile application in the value chains of } \\
\text { manufacturing, advanced products and production } \\
\text { systems and system services in the sectors of software } \\
\text { and IT consultancy, information services, manufacture } \\
\text { of electrical equipment, machines, devices, computers, } \\
\text { electronic and optical products }\end{array}$ & $\begin{array}{l}\text { IT is defined as a perspective } \\
\text { industry for smart } \\
\text { specialization (Lvivska oblast). }\end{array}$ \\
\hline \multirow[t]{2}{*}{$\begin{array}{l}\text { Podkarpackie } \\
\text { voivodship }\end{array}$} & $\begin{array}{l}\text { Automotive. Manufacture of cars, buses, minibuses, } \\
\text { motorcycles, tractors, semi-trailers, trailers; } \\
\text { manufacture of rolling stock, surface and } \\
\text { underground, as well as overhead railways; } \\
\text { manufacture of products which are ultimately used in } \\
\text { the automotive sector, including engines; research and } \\
\text { development directly related to the wider automotive } \\
\text { sector, aimed at implementing research results in } \\
\text { production and society. }\end{array}$ & $\begin{array}{l}\text { Production of railway } \\
\text { locomotives and rolling stock, } \\
\text { production of machines and } \\
\text { equipment for agriculture and } \\
\text { forestry, production of } \\
\text { assemblies, details, and } \\
\text { devices for vehicles (Lvivska } \\
\text { oblast). }\end{array}$ \\
\hline & $\begin{array}{l}\text { Quality of life. Mobility (sustainable transport); } \\
\text { climate and energy (renewable energy sources and } \\
\text { related technologies); sustainable tourism (excluding } \\
\text { mass tourism); Health, food, nutrition, innovative } \\
\text { technologies, processes and products of the agri-food } \\
\text { sector, highest biological and health quality. }\end{array}$ & $\begin{array}{l}\text { Food production (Lvivska } \\
\text { oblast). }\end{array}$ \\
\hline
\end{tabular}

Tab. 1. Similar types of economic activity defined as smart specialization priorities by RIS3 and Regional Development Strategies in Ukraine-Poland cross-border region. Source: developed by authors based on [21-24].

The analysis provided in Tables shows that Lvivska and Chernivetska oblasts have several types of economic activity that fall within the scope of smart specialization priorities of the adjoining regions from the neighboring countries within the respective cross-border regions. Volynska and IvanoFrankivska oblasts also have opportunities to join efforts with neighboring regions in bioeconomy and advanced production technologies, respectively. Meanwhile, Zakarpatska oblast, being geographically in both cross-border regions, doesn't have the types of economic activity that are the points of common interest in terms of smart specialization with the regions from the neighboring states. 


\begin{tabular}{|c|c|c|}
\hline $\begin{array}{l}\text { Region of the } \\
\text { neighboring } \\
\text { state }\end{array}$ & $\begin{array}{c}\text { Smart specialization priority of the region of the } \\
\text { neighboring state }\end{array}$ & $\begin{array}{l}\text { Similar priorities of } \\
\text { Ukrainian regions within the } \\
\text { respective cross-border } \\
\text { region }\end{array}$ \\
\hline \multirow[t]{2}{*}{$\begin{array}{l}\text { North-West } \\
\text { Romania }\end{array}$} & $\begin{array}{l}\text { Advanced Production Technologies. Encompasses } \\
\text { economic activities related to the production of } \\
\text { machinery and equipment which account for high } \\
\text { concentration of companies and turnover in the } \\
\text { region. Specialization niches include: innovative } \\
\text { machinery and equipment in robotics, mechatronics, } \\
\text { automation, advanced manufacturing and processing, } \\
\text { additive manufacturing / rapid prototyping; } \\
\text { innovative machinery and equipment for energy } \\
\text { production using renewable sources or generating } \\
\text { less pollution; machinery, equipment and solutions } \\
\text { for energy efficiency. }\end{array}$ & $\begin{array}{l}\text { Production of electric engines, } \\
\text { generators, power converters, } \\
\text { energy distribution and } \\
\text { control equipment, } \\
\text { production of machinery and } \\
\text { equipment of general use } \\
\text { (Ivano-Frankivska oblast). }\end{array}$ \\
\hline & $\begin{array}{l}\text { Agri-Food. The sector is well anchored in the regional } \\
\text { economy with a significant number of employees and } \\
\text { a large number of firms. Despite low income levels it } \\
\text { has been supporting the development of rural } \\
\text { economy given that almost half of the region's } \\
\text { population lives in rural areas. Specialization niches: } \\
\text { production of safe, healthy, affordable and } \\
\text { nutritionally optimized food products based on local } \\
\text { breeds and crops, culinary traditions and by applying } \\
\text { the principles of High Nature Value Farming, } \\
\text { sustainable and precision agriculture, as well as new } \\
\text { veterinary and agricultural genetics; and production } \\
\text { of functional foods. }\end{array}$ & $\begin{array}{l}\text { Food production } \\
\text { (Chernivetska oblast). }\end{array}$ \\
\hline \multirow[t]{3}{*}{$\begin{array}{l}\text { North-East } \\
\text { Romania }\end{array}$} & $\begin{array}{l}\text { Textile - clothing sector. (advanced biomaterials, } \\
\text { functional textiles, medical textiles, smart textiles for } \\
\text { interconnecting clothing, biomaterials, technical } \\
\text { textiles, textile composite structures, knitted } \\
\text { structures with thermal properties, mechanical } \\
\text { protection knits, clothing synergistic). }\end{array}$ & $\begin{array}{l}\text { Textile production (Ivano- } \\
\text { Frankivska oblast). } \\
\text { Textile production } \\
\text { (Chernivetska oblast). }\end{array}$ \\
\hline & $\begin{array}{l}\text { Healthy Ageing, Healthy Living and Tourism. } \\
\text { Adventure and active tourism, healthy ageing, } \\
\text { cultural tourism. }\end{array}$ & $\begin{array}{l}\text { Tourism and recreation } \\
\text { development (Chernivetska } \\
\text { oblast). }\end{array}$ \\
\hline & $\begin{array}{l}\text { Agro-food sector. Agronomy, crop science, food } \\
\text { science, biotechnology, soil research, nano-materials } \\
\text { for protein separation). }\end{array}$ & $\begin{array}{l}\text { Food production } \\
\text { (Chernivetska oblast). }\end{array}$ \\
\hline
\end{tabular}

Tab. 2. Similar types of economic activity defined as smart specialization priorities by RIS3 and Regional

Development Strategies in Ukraine-Romania cross-border region. Source: developed by authors based on [21], [25], [26].

There are four cross-border clusters with participants from Ukraine. All of them are in the UkrainePoland cross-border region. Two clusters are in tourism, one in innovations and one in statistics. Yet, the efficiency of their activity is doubtful. At least, information on their activity is hardly accessible as there are no official websites or social media or even any updated links at the websites of clusters participants. Nevertheless, the analysis of regional clusters in Ukraine-Poland and Ukraine-Romania cross-border regions shows that many of them have similar or complementary functioning areas. Some of them and the initiatives to establish the clusters that are at the stage of finalization are presented in Table 3. 


\begin{tabular}{|c|c|c|}
\hline Location & Cluster & $\begin{array}{l}\text { Similar clusters and initiatives by the types of } \\
\text { activity in Ukrainian oblasts within the respective } \\
\text { cross-border region }\end{array}$ \\
\hline $\begin{array}{l}\text { Lubelskie } \\
\text { voivodship }\end{array}$ & $\begin{array}{l}\text { Lublin Medicine-Medical } \\
\text { and Wellness Cluster }\end{array}$ & $\begin{array}{l}\text { Medical Tourism Cluster, Biotech \& Pharma Cluster } \\
\text { (Lvivska oblast) }\end{array}$ \\
\hline \multirow{2}{*}{$\begin{array}{l}\text { Podkarpackie } \\
\text { voivodship }\end{array}$} & East Automotive Alliance & Automotive cluster initiative (Zakarpatska oblast) \\
\hline & Polish automotive group & Automotive cluster initiative (Zakarpatska oblast) \\
\hline $\begin{array}{l}\text { North-East } \\
\text { Romania }\end{array}$ & $\begin{array}{lll}\text { Astrico } & \text { Nord-Est } & \text { Textile } \\
\text { Cluster } & & \end{array}$ & $\begin{array}{l}\text { Cluster of Popular Art Industries "Suzirya" (Ivano- } \\
\text { Frankivska oblast), wedding industry cluster initiative } \\
\text { (Chernivetska oblast) }\end{array}$ \\
\hline \multirow{4}{*}{$\begin{array}{l}\text { North-West } \\
\text { Romania }\end{array}$} & Agro Transylvania Cluster & Apple Cluster "Bukovyna" (Chernivetska oblast) \\
\hline & $\begin{array}{l}\text { Eco-Innovation Cluster for } \\
\text { Sustainable Environment }\end{array}$ & $\begin{array}{l}\text { Precarpathian Eco-Energy Cluster (Ivano-Frankivska } \\
\text { oblast) }\end{array}$ \\
\hline & Transylvania Energy Cluster & $\begin{array}{l}\text { Precarpathian Eco-Energy Cluster (Ivano-Frankivska } \\
\text { oblast) }\end{array}$ \\
\hline & $\begin{array}{ll}\text { Transylvania } & \text { Creative } \\
\text { Industries Cluster } & \end{array}$ & $\begin{array}{l}\text { Cluster of Popular Art Industries "Suzirya" (Ivano- } \\
\text { Frankivska oblast), wedding industry cluster initiative } \\
\text { (Chernivetska oblast) }\end{array}$ \\
\hline
\end{tabular}

Tab. 3. Some clusters and initiatives in the regions of Poland and Romania adjoining Ukraine that function in the types of activities related to those of clusters in the respective Ukrainian oblasts within the respective cross-border regions.

Source: developed by author based on [27], [12].

In addition to these clusters, there are also other ones in Ukrainian oblasts that function in the types of economic activity that are the priorities of smart specialization for respective EU regions. They include Lviv IT Cluster and Lutsk IT Cluster (ICT is the priority of both Lubelskie and Podkarpackie voivodeships' RIS3), Energy Cluster "Innovation Energy" (Low-carbon emission energy is the priority of Lubelskie voivodeship RIS3), ClusterBit and IT Cluster Ivano-Frankivsk (ICT is the priority of NorthWest Romania). Moreover, we should mention the initiative of creating the wood processing cluster in Chernivetska oblast as it correlates with North-West Romania's smart specialization priority "New Materials - Furniture, Paper and Packaging, Plastics and Metal Processing".

Therefore, there are preconditions for Ukrainian clusters to overcome the national border to cooperate with existing clusters in the EU and with the companies in similar types of activity to establish new partnerships based on similar specialization areas. In this regard, our research of similar smart specialization priorities shows that there are points of common interest for the territories in crossborder regions of Ukraine with the EU Member States. Therefore, there are grounds for developing a joint cross-border approach to strategizing in these cross-border regions.

\section{CONCLUSIONS}

The support the EU provides to the regions to promote their cooperation with the view to develop a shared vision of co-existence with neighboring regions that are similar in economic, social, cultural, and historical aspects based on smart specialization principles, the practical steps already accomplished towards this end, and the interest in the issue on the part of scientists and researchers testify to the fact that there will be much more initiatives regarding the creation of cross-border smart specialization partnerships and strategies in the next program period.

As for Ukraine, currently, the approaches to the development of strategic documents are undergoing substantial changes. The strategies of oblasts' development for 2021-2027 are already grounded on the principles of smart specialization. Yet, the comparing of these documents with those developed in the EU regions is a difficult task. Ukrainian strategies are quite different, in the first place because of the lack of necessary data to calculate the specialization according to the EU methodology. Nevertheless, one can argue that the first attempts to apply the smart specialization approach to 
strategic planning are quite successful, and the priorities are defined in correspondence with the regions' development, although they are much narrower than the cross-sectoral priorities of EU regions. It is a step towards involvement in global value chains and entrance to European and global markets, which is rather doubtful without the consideration of smart specialization as an advanced tool of regional development planning. It is also a chance to gain access to structural and investment funds of the European Union.

The first attempts in our paper to outline the grounds for cross-border regions of Ukraine to apply a smart specialization approach to strategizing their development show that border regions in UkrainePoland and Ukraine-Romania cross-border regions have the points of common interests in terms of smart specialization priorities. Moreover, the clusters, which are the main tool of smart specialization priorities implementation in the EU, are present at adjoining territories, and the types of economic activity they function in are similar or complementary to those located on the other side of the border. It is the basis for the establishment of cluster partnerships across the borders. The close cross-border cooperation links in these cross-border regions do not raise any questions either, starting from historical retrospective up till nowadays, when there are common governing structures operating under the Euroregions and numerous examples of projects implemented under the CBC Programs that include activities in innovations, research, education, and SME support. These are the factors that should be considered as preconditions to elaborate on the strategies of cross-border regions' development based on the principles of smart specialization in the EU-Ukraine cross-border space.

\section{REFERENCES}

[1] Communication from the Commission to the European Parliament, the Council, The European Economic and Social Committee and the Committee of the Regions. Europe 2020 Flagship Initiative Innovation Union, SEC 1161 (2010). Available at: https://ec.europa.eu/research/innovation-union/pdf/innovation-unioncommunication_en.pdf

[2] Lundquist K.-J., Trippl M. Distance, Proximity and Types of Cross-Border Innovation Systems: A Conceptual Analysis. Regional Studies, 3 (47) (2013), 450-460. doi: 10.1080/00343404.2011.560933

[3] Van den Broek J., Smulders H. Institutional Hindrances in Cross-border Regional Innovation Systems. Regional Studies. Regional Science, 2 (1) (2015), 115-121. doi: 10.1080/21681376.2015.1007158

[4] Weidenfeld A. Tourism and cross-border regional innovation systems. Annals of Tourism Research, 42 (1) (2013), 191-213. doi: 10.1016/j.annals.2013.01.003

[5] Doloreux D., Parto S. Regional innovation systems: Current discourse and unresolved issues. Technology in society, 27 (2) (2015), 133-153. doi: 10.1016/j.techsoc.2005.01.002

[6] Makkonen T., Rohde S. Cross-border regional innovation systems: conceptual backgrounds, empirical evidence and policy implications. European Planning Studies, 24 (9) (2016), 1623-1642. doi: 10.1080/09654313.2016.1184626

[7] Hansen T. Bridging regional innovation: cross-border collaboration in the Oresund Region. Geografisk Tidsskrift-Danish Journal of Geography, 113 (1) (2013), 25-38. doi: 10.1080/00167223.2013.781306

[8] Regional Innovation Strategy of the Ślaskie Voivodeship for the years 2013-2020. Available at: https://s3platform.jrc.ec.europa.eu/documents/20182/231100/PL_Slaskie_RIS3_Final.pdf/f8fdfcad-5a284d0a-bd89-c5ee25ee974a

[9] Smart Stories. Implementing smart specialization across Europe. Available at: https://ec.europa.eu/jrc/en/publication/thematic-reports/smart-stories-implementing-smartspecialisation-across-europe

[10] The Vanguard Initiative. Available at: https://ec.europa.eu/growth/tools-databases/regional-innovationmonitor/link/vanguard-initiative 
[11] Prytula Kh.M., Demedyuk O.P. Tools of implementation of smart specialization strategies in the EU Member States. Socio-Economic Problems of the Modern Period of Ukraine, 2 (142) (2020), 62-70. doi: 10.36818/2071-4653-2020-2-9

[12] Demedyuk O.P. Perspectives of the development of cross-border clusters in the border oblasts of the Western Ukraine. Regional economy, 2 (96) (2020), 58-71. doi: 10.36818/1562-0905-2020-2-5

[13] The KNOW-HUB project. Available at: http://know-hub.eu/about-know-hub/the-know-hub-project.html.

[14] TR3S. Available at: http://www.tr3s-project.eu/information/

[15] The project. Available at: https://interreg-poctefa-access.com/en/home-en/

[16] Project-Smart Specialization. Available at: https://www.keep.eu/project/9647/smart-specialization

[17] Navarro M. Regional Cross-Border Cooperation and Ris3. European Territorial Framework Virtual Library, 2018. Available at: http://projects.mcrit.com/foresightlibrary/attachments/article/1155/Navarro \%20(2018)\%20Regional\%20Cross-Border\%20Cooperation\%20and\%20Ris3.pdf

[18] Muller E., Zenker A., Hufnagl M., Heraud J.A., Schnabl E., Makkonen T., Kroll H. Smart specialisation strategies and cross-border integration of regional innovation systems: Policy dynamics and challenges for the Upper Rhine. Environment and Planning C Government and Policy, 35 (4) (2017), 684-702 doi: $10.1177 / 0263774 \times 16688472$

[19] Cross-Border Smart Specialization Strategy of Galicia-Northern Portugal. Available at: http://www.ris3galicia.es/wp-content/uploads/2016/07/RIS3T_INGLES.pdf

[20] Creating Growth through Trans-national Cooperation and Value Chains. Available at: https://s3platform.jrc.ec.europa.eu/documents/20182/154989/Smart+Specialisation+Creating+Growth+th rough+Trans-national+cooperation+and+Value+Chains/f3587cf2-c511-42a4-b559-a89d511a7e38

[21] Eye@RIS3: Innovation Priorities in Europe. Available at: https://s3platform.jrc.ec.europa.eu/map

[22] 2021-2027 Lvivska Oblast Development Strategy. Available at: https://www.minregion.gov.ua/napryamkidiyalnosti/derzhavna-rehional-na-polityka/strategichne-planuvannya-regionalnogo-

rozvitku/regionalni-strategiyi-rozvytku-na-period-do-2027-roku/strategiya-rozvytku-lvivskoyi-oblastina-period-2021-2027-rokiv/

[23] 2027 Volynska Oblast Development Strategy. Available at: https://www.minregion.gov.ua/wpcontent/uploads/2020/04/volynska-strategiya-rozvytku-volynskoyi-oblasti-na-period-do-2027-roku.pdf

[24] 2021-2027 Regional Zakarpatska Oblast Development Strategy. Available at: https://www.minregion.gov.ua/napryamki-diyalnosti/derzhavna-rehional-na-polityka/strategichneplanuvannya-regionalnogo-rozvitku/regionalni-strategiyi-rozvytku-na-period-do-2027roku/regionalna-strategiya-rozvytku-zakarpatskoyi-oblasti-na-period-2021-2027-rokiv/

[25] 2021-2027 Ivano-Frankivska Oblast Development Strategy. Available at: https://www.minregion.gov.ua/napryamki-diyalnosti/derzhavna-rehional-na-polityka/strategichneplanuvannya-regionalnogo-rozvitku/regionalni-strategiyi-rozvytku-na-period-do-2027-roku/strategiyarozvytku-ivano-frankivskoyi-oblasti-na-2021-2027-roky/

[26] 2027 Chernivetska Oblast Development Strategy. Available at: https://www.minregion.gov.ua/napryamkidiyalnosti/derzhavna-rehional-na-polityka/strategichne-planuvannya-regionalnogorozvitku/regionalni-strategiyi-rozvytku-na-period-do-2027-roku/strategiya-regionalnogo-rozvytkucherniveczkoyi-oblasti-na-period-do-2027-roku/

[27] List of cluster organizations. Available at: https://www.clustercollaboration.eu/cluster-list

Address: Olha Demedyuk, Khrystyna Prytula, SI “The Institute of Regional Research Named after M.I. Dolishniy of the NAS of Ukraine", 4 Kozeknytska St., Lviv, 79026 Ukraine.

E-mail: olya_demedyuk@ukr.net; khrystynka.prytula@gmail.com

Received: September 10, 2020; revised: November 5, 2020. 
Демедюк Ольга, Притула Христина. Транскордонний підхід до смарт-спеціалізації регіонів: досвід країн-членів СС. Журнал Прикарпатського університету імені Василя Стефаника, 7 (3) (2020), 36-48.

Протягом останнього десятиліття країни Європейського Союзу активно реалізовують політику регіонального розвитку на основі інноваційних стратегій смарт-спеціалізації. Проте останнім часом європейські дослідники звертають все більше уваги на проблематику дослідження потенціалу регіонів не лише в межах адміністративних одиниць однієї країни, а з врахуванням потенціалів розвитку сусідніх регіонів, як в межах, так і за межами країни. Також важдиво вивчати регіони в контексті їх розвитку як елементів більш складних систем, особливо з точки зору посилення ролі їхніх інноваційних мереж у процесах інтеграції до глобальних ланцюгів вартості. Тому питання розробки транскордонних стратегій смарт-спеціалізації є на порядку денному у ЄС.

Метою статті є узагальнення досвіду країн ЄС щодо функціонування транскордонних інноваційних систем та стратегічного планування розвитку транскордонних регіонів на основі смартспеціалізації та окреслення можливостей імплементації досвіду ЄС у застосуванні підходу смартспеціалізації до визначення пріоритетів розвитку транскордонних регіонів України з країнамичленами ЕС.

Проаналізовано наукові розробки закордонних дослідників щодо взаємозв'язків між інноваційними регіональними системами у транскордонному просторі, які слугують базисом для розробки транскордонних стратегій смарт-спеціалізації, зокрема в контексті вимірів та рівнів їх розвитку. Узагальнено особливості функціонування транскордонних інноваційних систем у конкретних транскордонних регіонах, зокрема на іспансько-французькому та німецько-французькому кордонах.

Окреслено напрямки реалізації проектів щодо смарт-спеціалізації в транскордонному контексті за програмами $Є С$ та наведено інші інструменти $Є С$ щодо підтримки розвитку регіонів для розробки спільного бачення розвитку з сусідніми економічно, соціально, культурно та історично близькими регіонами.

Вивчено досвід та методологію написання першої транскордонної стратегії смарт-спеціалізації для іспанських та португальських регіонів.

Проаналізовано перспективи застосування кращих практик ЄС деякими областями Західного регіону України на основі подібних сфер спеціалізації. 3 цією метою здійснено порівняння пріоритетів стратегій смарт-спеціалізації регіонів Польщі та Румунії, що межують з Україною, та стратегій розвитку відповідних українських областей та виявдено наявність кдастерів як основних інструментів досягнення цілей смарт-спеціалізації з подібними чи комплементарними сферами діядьності по обидва боки державного кордону.

Кдючові слова: регіональні інноваційні системи, транскордонні інноваційні системи, країни Європейського Союзу, смарт-спеціалізація, транскордонний регіон, транскордонна стратегія смартспеціалізації, регіональні інноваційні стратегії смарт-спеціалізації, кластери. 